Iastremska 0 ., Gerasymov 0.

\title{
THEORETICAL AND METHODOLOGICAL PROVISION OF JUSTIFICATION OF THE ENTERPRISE ACTIVITY EFFICIENCY IN THE MARKETING ASPECT
}

Об’єктом дослідження є прочес визначення основних напрямів підвищення ефективності діяльності підприємства у маркетинговому аспекті, тобто з урахуванням як особливостей його внутрішнього середовища, так і суб'єктів ринку, тобто зовнішнього оточення. Однією з проблем є недостатнє врахування сучасного понятійного апарату ефективності. Окрім того важливе значення має у деяких випадках вузьке формування мети проекту без урахування маркетингового аспекту. Перешкодою може бути складність розроблення переліку критерїв щодо відбору відповідальних виконавців проекту. Часто зустрічається неповнота врахування стратегічних та поточних проблем з підвищення ефективності діяльності підприємства у маркетинговому аспекті.

Обгрунтовано та розроблено пропозицї з уточнення визначення понять «ефективність» та «маркетинговий аспект», використання проектного підходу, що враховує дві основні складові ефективності. До них відносяться: об’єктивна щодо використання ресурсного потенщіалу підприємств та суб'єктивна, яка враховує особливості інформащійно-комунікаційної та маркетингової взаємодії суб'єктів ринку. Ці складові ефективності дозволили усунути виявлені недоліки дослідженої проблеми.

Основним результатом дослідження є обгрунтована й запропонована змістовність та послідовність етапів методичного забезпечення визначення напрямів підвищення ефективності діяльності підприємства у маркетинговому аспекті. На першому етапі доцільно сформувати мету проекту. На другому - розробити критерї щодо відбору та призначення відповідальних виконавців. Третій етап передбачає визначення та здійснення комплексного аналізу стратегічних та поточних проблем з підвищення ефективності діяльності підприємства у маркетинговому аспекті. На четвертому етапі доцільно здійснити визначення стратегічної мети та ї структуризащію. П'ятий етап - обгрунтування основних напрямів підвищення ефективності. На шостому етапі доцільне формування альтернативних варіантів щодо досягнення цілей. На сьомому етапі слід оптимізувати фінансові, кадрові, виробничі, інноваційні, інформаційно-комунікаційні та маркетингові витрати проекту. Восьмий етап - розподіл відповідальності за реалізацію проекту між структурними підрозділами підприємства.

При практичній реалізацї розробленого методичного забезпечення існує реальна можливість переходу на альтернативні варіанти реалізації проекту в умовах постійних трансформацій, що сприяє формуванню економічного ефекту на макро-, мезо- та мікроекономічному рівнях.

ключові слова: ефективність діяльності підприємства, маркетинговий аспект, методичне забезпечення, проектний підхід, економічний ефект.

Received date: 14.02.2020

Accepted date: 17.03 .2020

Published date: 30.06 .2020
Copyright (c) 2020, Iastremska O., Gerasymov O. This is an open access article under the CC BY license (http://creativecommons.org/licenses/by/4.0)

\section{Introduction}

The integration of Ukrainian enterprises into the world economic space is influenced by many factors. This is accompanied by a significant increase in competition, the saturation of certain markets, the inability to make a technical and technological breakthrough. This especially applies to work with regular and potential customers, the implementation of effective advertising campaigns, informative marketing research and so on. Therefore, it is impossible to overcome the shortcomings of all these characteristics without improving the efficiency of enterprises in the marketing aspect, i. e. taking into account the peculiarities of the interac- tion of market participants. This determines the feasibility of identifying and gradual and systematic implementation of areas to improve the efficiency of enterprises, which should be specified in the form of projects to improve efficiency in the marketing aspect. Therefore, this problem is relevant and needs further research and solution.

\section{The object of research and its technological audit}

The object of research is the process of determining the main directions of improving the efficiency of the enterprise in the marketing aspect, i. e. taking into account 
both the peculiarities of its internal environment and market participants, i. e. the external environment. It seems expedient of basing research on modern understanding of the concepts of «efficiency» and «marketing aspect» while developing ways of increasing the efficiency of the enterprise. Also, in determining local and global priorities for its provision. In addition, in identifying existing problems by objective and subjective components using their sound system of performance indicators. Therefore, it is necessary to identify alternatives to eliminate the identified problems by components, which should be implemented organizationally using a project approach. The project to increase the efficiency of the enterprise in the marketing aspect must take into account the views of suppliers, competitors, consumers, which are taken into account in reasonable and proposed indicators. However, the focus should be on changing the lowest quantitative value of the indicator that has been determined. The outlined problem is insufficiently considered in the modern scientific literature, which, in turn, indicates the need for its further study.

\section{The aim and objectives of research}

The aim of research is the development of theoretical and methodological support for the justification of the effectiveness of the enterprise in the marketing aspect.

To achieve this aim, it is necessary to perform the following scientific objectives:

1. Clarify the definition of the basic theoretical concepts of the effectiveness of the enterprise in the marketing aspect.

2. Identify the stages of formation of methodological support to determine the main directions of improving the efficiency of the enterprise in the marketing aspect.

\section{Research of existing solutions to the problem}

Generalization of research on the theoretical basis for the efficiency of enterprises and in the marketing aspect proved that most considered the effectiveness and be in comparison and achieved effect to the cost of obtaining it [1,2]. This doesn't allow to take into account that the key advantage of the efficiency of the enterprise is the conditions of the enterprise, which are constantly changing. In [3] it is rightly proposed to consider the efficiency through the effectiveness of the enterprise and the implementation of its comprehensive assessment. However, no specific recommendations were provided on its indicators and components.

The study [4] indicates the need to determine the effectiveness of the components of the effect. This is an advantage of this proposal, but the proposed components are not distributed by internal and external environments. With the development of market relations, the center of gravity of the effect gradually began to shift from the internal environment to the external environment, i. e. to market participants [5, 6]. Such a proposal is justified, but the authors do not specify the indicators that characterize the components of the external environment. In this regard, it is advisable to take into account the factors and indicators that characterize market participants. It is consumers, partners, competitors and authorities, by meeting their own needs through the consumption of products of enterprises, contribute to the formation of the effect of their activities and ensure economic efficiency. Thus, there is an objective need to take into account the existing relationship between the formation of economic efficiency of the enterprise and its provision with marketing tools, i. e. consideration of the first in the marketing aspect. To develop approaches to assessing and ensuring the growth of economic efficiency of enterprises, it is necessary to clarify the definition of the basic concepts of this process, taking into account the growing influence of market participants on its course. The key factors for ensuring efficiency are the marketing mix, consumer behavior and the resulting marketing [7], but in today's conditions it is necessary to focus on the coordination of strategic and current goals of the company and its key stakeholders.

The analysis of scientific works on the development and implementation of projects to improve efficiency [8,9], which emphasize the feasibility of applying the project approach in a constantly changing environment. Approaches to the process of project organization are studied [10, 11]. The peculiarities of strategic planning of the project management procedure are analyzed [12]. Suggestions for improving the efficiency of the enterprise are considered [13, 14], but they do not take into account the marketing aspect, which is the most important in modern conditions. The results of the analysis indicate a lack of in-depth study of this problem, which does not take into account the trends of humanization, socialization, consumerization of the economy. It is these trends that actualize the marketing aspect to achieve the efficiency of the enterprise. And also prove the feasibility of combining the objective component of efficiency in relation to the use of resource potential of the enterprise and the subjective component of information and communication exchange of marketing information between the enterprise, consumers, suppliers and other market participants [15].

Thus, it is proposed to base the objective component on the results of the calculation of the integrated indicator, which is formed by financial, personnel, production, innovation areas. To calculate it, a reasonable system of partial indicators of the use of economic resources of the enterprise is used. Partial indicators are determined by the main identified explicit and latent trends in its activities. All this is the basis for ensuring and increasing efficiency. It is proposed to determine the subjective component according to a reasonable system of qualitative indicators based on the use of expert methods. With their further transformation into quantitative in marketing and information and communication areas to identify expectations and peculiarities of perception of the enterprise. It is effective from the standpoint of consumers, suppliers and competitors, i. e. market participants - in the marketing aspect, which will take into account the effectiveness of information flows and the use of marketing software [16].

Thus, the main scientific works on improving the efficiency of the enterprise in the marketing aspect are summarized, the main components of its definition are identified. The use of the proposed components in a dynamically changing external market environment becomes especially acute.

\section{Methods of research}

During the work general scientific and special research methods were used:

- analysis and synthesis - for preliminary analysis with the formation of the problem, defining goals, clarifying the definition of «efficiency» and «marketing aspect», identifying the stages of formation of methodological 
support to determine the main directions of improving the efficiency of the enterprise in marketing;

- comparative analysis - to identify the stages of development and implementation of the project to improve the efficiency of the enterprise in the marketing aspect; - decomposition method - for the formation of an indicative graph of cause-and-effect relationships;

- structuring method - for the formation of the structure of strategic and current project objectives.

\section{Research results}

Joining the interpretation of efficiency through the concepts of «results» and «costs», it is worth noting that efficiency can vary depending on the goals. That is, any subjective predominance can change the conclusion about the effectiveness of the process or phenomenon. Therefore, efficiency, according to the nature of its origin, can be perceived not only as an objective but also as a subjective, personal assessment. It is this combination of objectivity and subjectivity of the perception of economic efficiency corresponds to modern views of behavioral economics. Indeed, objectivity is provided by the available economic resources that characterize the ability of enterprises to produce products or provide services of a certain quality. Subjectivity depends on the expectations and expectations of the main market participants: consumers, suppliers, partners, competitors to meet their needs, the availability of effective demand for products or services.

Thus, the specified definition of economic efficiency of activity of the enterprise consists that under this concept it is expedient to understand degree of maintenance of authenticity of subjective expectations and expectations of subjects of the market. Taking into account their effective demand for the quality and volume of production and provision of services by the enterprise through the use of economic resources is an objective basis for achieving certain results. The proposed definition corresponds to both the modern theory of behavioral economics and takes into account the classical understanding of economic efficiency, especially the functioning of the market environment. Because the profit, i. e. the effect, is formed precisely by meeting the demand for products by enterprises, i. e. occurs in the external environment, which should be determined on the basis of marketing information market research. That is, to consider economic efficiency in the marketing aspect, taking into account the internal resource capabilities of the enterprise. In summary, it is worth emphasizing that the feature of the refined definition of economic efficiency is to take into account the objective capabilities and subjective expectations regarding the results of the enterprise, which corresponds to the modern economic paradigm of functioning and development of economic entities in a competitive environment.

It is advisable to define the concept of «marketing aspect», as the company must conduct market research on the subjects of the external environment, which is a sufficient number of varieties and it needs to focus on the priority ones, using the principle of limited rationality. Such subjects are consumers, suppliers, i. e. partners, and competitors, on the direct action of which depends the economic efficiency of the enterprise. It is important to note that their activities in the market for the company are interdependent and based on its objective resource capabilities. Therefore, each of them must be considered and studied not separately, but systematically in the triad of «suppliers - consumers - competitors». Because such a division is conditional and each of them can change its role at any time, for example, to cease to be a consumer and become a supplier or competitor. Thus, to achieve economic efficiency, it is advisable to take into account the marketing aspect of the enterprise, which is proposed to understand the study of market participants in the relationship of the triad «suppliers - consumers - competitors», which is important for its operation and development. The peculiarity of the revised definition is the association of the most influential subjects of the external environment in the triad «suppliers - consumers - competitors», which is a priority to ensure the efficiency of the enterprise from the standpoint of its external environment. Refined definitions are a theoretical basis for determining areas for improving the efficiency of the enterprise in today's dynamic economic conditions.

Regarding the methodological support, the comparative analysis of literature sources [12, 17] on this issue is the core of identifying the stages of development and implementation of the project to improve the efficiency of the enterprise in the marketing aspect. This is the basis of the proposed methodological support, which should be carried out in the following stages:

1. Forming the purpose of the project to improve the efficiency of the enterprise in the marketing aspect.

2. Development of a list of criteria for the selection of responsible project executors.

3. Selection and appointment of responsible executors for the formation of the project to improve the efficiency of the enterprise in the marketing aspect.

4. Identification of strategic and current problems to improve the efficiency of the enterprise in the marketing aspect.

5. Carrying out a comprehensive analysis of strategic and current problems to improve the efficiency of the enterprise in the marketing aspect in order to identify sources of their occurrence and factors of influence.

6. Defining a strategic goal and its structuring.

7. Substantiation of the main directions of increasing the efficiency of the enterprise.

8. Formation of alternative ways to achieve the goals that have been set.

9. Preparation of alternative options for project implementation to improve the efficiency of the enterprise in the marketing aspect.

10. Optimization of financial, personnel, production, innovation, information and communication and marketing costs of the project.

11. Distribution of responsibility for project implementation between structural units of the enterprise.

At the first stage, which concerns the issue of forming the purpose of the project to improve the efficiency of the enterprise in the marketing aspect, it is advisable to first identify alternative goals that can be set within the project. Analysis of scientific works [18, 19] shows that the most common goals are:

- maximizing the level of consumption, i. e. companies are trying to increase sales [20];

- maximization of consumer satisfaction, based on the identified explicit and implicit needs of consumers, and the production of products that best meet them [21]; 
- maximization of choice, which involves the presence in a particular market of a significant number of modifications of goods, taking into account the requirements of the most demanding consumers. This goal is in fact a continuation of the previous one [22];

- maximizing the quality of life, which helps to ensure the availability of goods at reasonable prices in a certain quantity with a certain level of quality, characterized by diversity and accessibility, improve the quality of socio-cultural, physical, ecological living environments [23, 24].

In the second stage, it is advisable to develop a list of criteria for the selection of responsible project executors. Of particular importance is the work of the project manager. According to the existing opinions of scientists and current standards for project management, the professional abilities of the project manager are determined by:

- ability to structure the mission of the project and form a list of specific tasks, schematic design of business processes, the main types of work, ways and methods of their implementation;

- ability to ensure the achievement of the project goal in terms of specific constraints, using adequate methods of planning, management of performers, coordination and control over project implementation;

ability to achieve the fullest comprehensive satisfaction of all stakeholders of the project, coordinating the process of resolving various conflicts of interest $[8,9]$.

At the third stage, the selection and appointment of responsible executors for the formation of the project to improve the efficiency of the enterprise in the marketing aspect, i. e. the project team is actually formed.

At the fourth stage, the definition of strategic and current problems to improve the efficiency of the enterprise in the marketing aspect.

The analysis of strategic and current problems to improve the efficiency of the enterprise in the marketing aspect should be carried out on the basis of a survey of leading managers of the enterprise and the current reporting data. The use of the proposed information helps to identify the main strategic and current issues that affect the effectiveness of enterprises in the marketing aspect, as well as is the basis for determining areas for their elimination.

The list of strategic and current problems related to improving the efficiency of the enterprise in the marketing aspect is presented in Table 1. They were identified by the results of evaluating the effectiveness of the enterprise on the objective and subjective [16] components, which are based on the definition of quantitative and qualitative indicators.

The list of strategic and current problems related to improving the efficiency of the enterprise in the marketing aspect, presented in Table 1 is confirmed by the results of evaluating the effectiveness of the enterprise on the objective and subjective [16] components. Namely, the insufficient level of the obtained value of the integrated evaluation of the efficiency of the enterprise by the objective and subjective components, the generalized integrated indicator of the evaluation of the efficiency of the enterprise in the marketing aspect. At the same time, the presented definitions of each problem do not exhaust their content. The proposed list identifies problems, and only managers of a certain level have a complete idea of their nature, causes, interaction on other and possible areas of neutralization.
Table 1

The list of strategic and current problems related to improving the efficiency of the enterprise in the marketing aspect

\begin{tabular}{|l|c|}
\hline \multicolumn{1}{|c|}{ Problem } & $\begin{array}{c}\text { Prob } \\
\text { co }\end{array}$ \\
\hline $\begin{array}{l}\text { Lack of defined goals and areas to improve the efficiency of the } \\
\text { enterprise as a whole }\end{array}$ & \\
\hline Lack of defined marketing goals of the enterprise & \\
\hline Lack of a program (plan) of marketing activities at the enterprise & 3 \\
\hline $\begin{array}{l}\text { Insufficient coordination of different areas of activity at the } \\
\text { enterprise }\end{array}$ & \\
\hline
\end{tabular}

\begin{tabular}{|l|l}
\hline Insufficient quality of personnel for marketing management & 5
\end{tabular}

Insufficient assessment of weaknesses and strengths of the enterprise, market opportunities and threats

Insufficient definition of alternative options for the implementation

of activities of the enterprise in the marketing aspect

Lack of methods for assessing the effectiveness of the enterprise in the marketing aspect

Lack of analysis and further improvement of relationships and relationships with the external environment

Lack of a clear division of responsibilities between all structura units of the enterprise that accept students in the implementation of projects to improve the efficiency of the enterprise in the marketing aspect

Imperfection of the legal framework for regulating supply and demand, the level of monopoly, the implementation of exportimport activities

\begin{tabular}{|l|l}
\hline Low level of use of modern marketing technologies & 12
\end{tabular}

\begin{tabular}{|l|l}
\hline Low level of efficiency of marketing research & 13
\end{tabular}

\begin{tabular}{|l|l}
\hline Low level of efficiency of marketing information system & 14
\end{tabular}

\begin{tabular}{|l|l}
\hline Low level of efficiency of target market segmentation & 15
\end{tabular}

\begin{tabular}{|l|l}
\hline Low level of direct sales efficiency & 16
\end{tabular}

\begin{tabular}{|l|l} 
Low level of efficiency of product sales promotion & 17
\end{tabular}

Low level of efficiency of the commodity policy of the enterprise 18

Low level of efficiency of sales policy of the enterprise

Low level of efficiency in the formation of public opinion

19

Low level of efficiency of advertising activity of the enterprise

Low level of efficiency of brand application by the enterprise

There is no system of audit of marketing technologies

Unsatisfactory condition of marketing infrastructure

Low level of efficiency in the sale of innovative products

Insufficient level of acquisition of new technologies, results of research and development

Insufficient level of quality of professional training

27

Insufficient level of increasing the efficiency of the enterprise in terms of the objective component

Insufficient level of increasing the efficiency of the enterprise on the subjective component

Insufficient level of efficiency of the enterprise in the marketing

aspect as a whole

6

10

Note: developed on the basis of data [2-4, 13-17]

Based on the proposed list of problems, it is advisable to analyze their relationships, which is the basis for determining the sequence of their actions to neutralize them. The problems that have been identified are characterized by the presence of cause-and-effect relationships, which is illustrated in Fig. 1. 


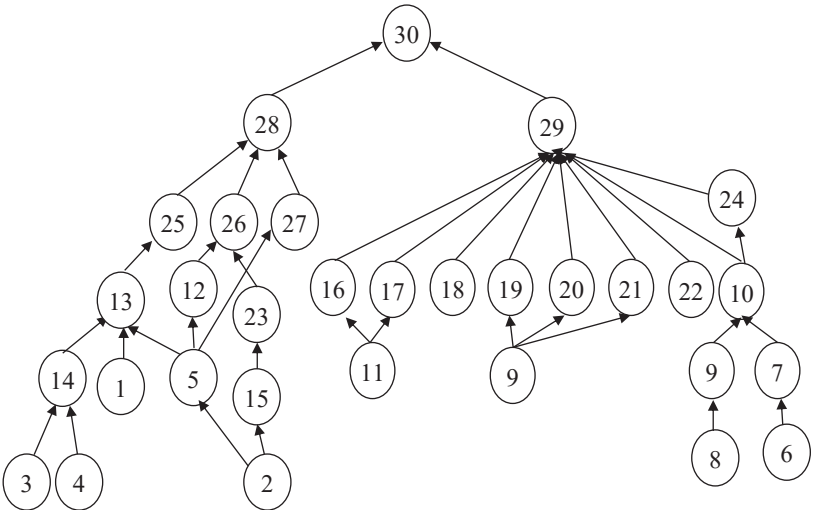

Fig. 1. Approximate graph of cause-and-effect relationships

Thus, the graph in Fig. 1 helps to increase the clarity and informativeness of the presentation of cause-and-effect relationships to increase the efficiency of the enterprise in the marketing aspect, reduce time and error in the formation of relevant projects and facilitate the identification of components of improvement. Analysis of the structure of the graph, which is presented in Fig. 1, indicates its consistency. The relationship of the problems considered in the column is determined by their nature and interdependence.

The solution presented in Fig. 1 problem is possible only on the basis of the implementation of certain projects for partial or complete solution. In particular, to solve problem 28 (insufficient level of efficiency of the enterprise by the objective component) it is advisable to implement the following steps of the project. This is a clarification of the marketing goals of the enterprise (2), improving the quality of personnel for marketing management (5), increasing the level of use of modern marketing technologies (12). In addition, increasing the level of acquisition of new technologies, research and development results (26). The implementation of these steps is one of the components of improving the efficiency of the enterprise in the marketing aspect.

The next stage of project development to improve the efficiency of the enterprise in the marketing aspect is to determine the strategic goal and its structuring. According to the results of the analysis of the list of strategic and current problems related to improving the efficiency of the enterprise in the marketing aspect and based on the requirements of the project, it is advisable to form a tree of goals. The goal tree can be represented as a graph showing how the strategic goal of the project is detailed in the current goals of the next level, etc. Thus, the tree is a connected graph that expresses the subordination and relationships of elements [9, 10]. In this case, such elements are strategic and current goals.

Representation of goals begins with the upper level, then they are sequentially disaggregated. In this case, the basic rule of structuring goals is completeness: each goal of the highest level must be presented in the form of sub-goals of the next level properly. The list of strategic and current goals formed according to the analysis of practical activity of domestic machine-building enterprises is presented in Table 2.

The structure of strategic and current goals of the project is presented in Fig. 2. When structuring goals, it is advisable to make a pairwise comparison in accordance with the relationship «necessity» and «general - partial», which helps to identify the content of goals and their formulation.
Table 2

\begin{tabular}{|l|c|}
\hline \multicolumn{1}{|c|}{ Strategic and current goals } & $\begin{array}{c}\text { Goal } \\
\text { codes }\end{array}$ \\
\hline $\begin{array}{l}\text { Increasing the efficiency of the enterprise in the marketing } \\
\text { aspect as a whole }\end{array}$ & 0.1 \\
\hline $\begin{array}{l}\text { Growth of efficiency of activity of the enterprise on an objective } \\
\text { component }\end{array}$ & 1.1 \\
\hline $\begin{array}{l}\text { Increasing the efficiency of the enterprise by the subjective } \\
\text { component }\end{array}$ & 1.2 \\
\hline Increasing the quality of professional training & 2.1 \\
\hline Growth of innovation activity & 2.2 \\
\hline Improving the financial condition of the enterprise & 2.3 \\
\hline Improving the production condition of the enterprise & 2.4 \\
\hline Increasing the efficiency of the company's brand & 2.5 \\
\hline Improving the state of the marketing infrastructure & 2.6 \\
\hline $\begin{array}{l}\text { Introduction and increase of efficiency of use of modern market- } \\
\text { ing technologies }\end{array}$ & 2.7 \\
\hline Formation of a system of audit of marketing technologies & 2.8 \\
\hline Improvement program (plan) marketing activities in the enterprise & 2.9 \\
\hline $\begin{array}{l}\text { Constant updating of the purposes and directions of increase of } \\
\text { efficiency of activity of the enterprise as a whole }\end{array}$ & 2.10 \\
\hline Improving information and communication support & 2.11 \\
\hline $\begin{array}{l}\text { The growth of responsibility between all structural units of the } \\
\text { enterprise, which take part in the implementation of projects to } \\
\text { improve the efficiency of the enterprise in the marketing aspect }\end{array}$ & 2.12 \\
\hline
\end{tabular}

Based on the list of strategic and current project objectives at the end of the planning period, it is advisable to assess the degree of achievement of project objectives. The analysis of scientific works shows that the corresponding assessment is possible to carry out both with the help of expert assessments $[25,26]$ and on the basis of accounting and statistical reporting. To ensure the objectivity and reliability of the study, the assessment was made on the basis of official statistical reporting of enterprises, which was processed by the authors, and the relevant indicators were calculated.

The goals of the first level (codes: 1.1, 1.2) are characterized by the presence of close relationships. This is due to the fact that the growth of the efficiency of the enterprise by objective and subjective components is the basis for the growth of the efficiency of the enterprise in the marketing aspect as a whole. The structuring of goals is carried out in accordance with the generalized relation $\mathrm{R}$, which characterizes the set of relations between strategic and current goals and measures. Also, exclusively between events. Thus, this means that of a pair of interrelated goals, one is dependent on the other, characterized by the presence of hierarchical relationships. At the same time, the goals of the first level, namely - to increase the efficiency of the enterprise by objective and subjective components, are not hierarchically dependent on each other, and therefore direct links between them according to the generalized relation $\mathrm{R}$ is not observed. The presence of the interaction of goals is observed only when structuring the goals of the first level on the goals of the second level, as well as in the process of cross-matching the goals of the second and subsequent levels with more general goals of the first level. Therefore, the presence of a connection between two goals of one or more levels necessarily characterizes them as complementary and indifferent, which contributes to their achievement. 


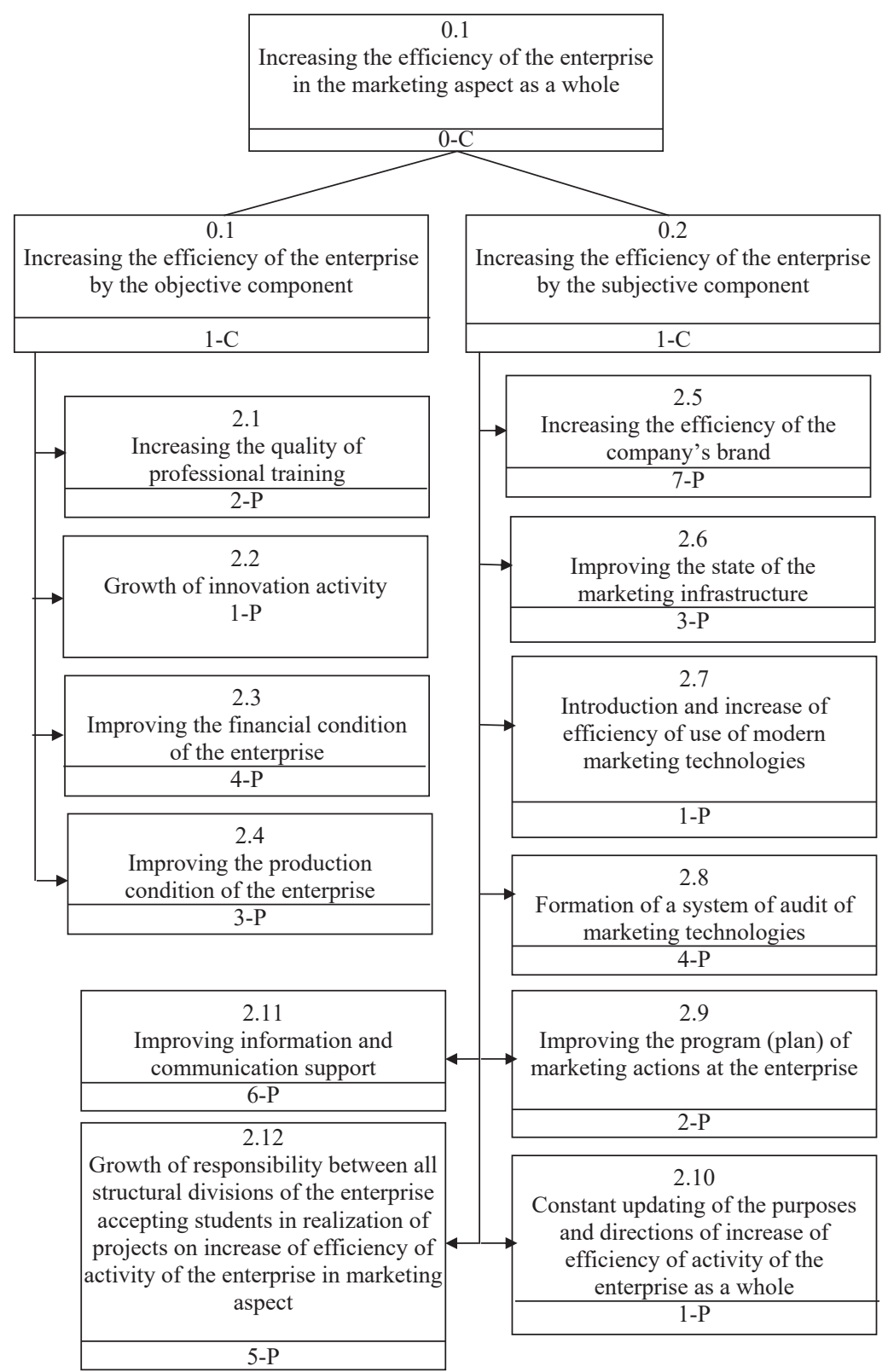

Fig. 2. Structure of strategic and current project goals

In the process of further structuring the strategic goals of the first level, identifying possible cross-links, twelve goals of the second current level were formed.

The next step is to determine the priorities for achieving the goals of each level. Expert methods were used to solve this problem. Top managers, heads of departments and divisions of machine-building enterprises of Kharkiv region (Ukraine) were involved as experts. The survey was conducted using a questionnaire, based on a questionnaire on the ranking of priorities for solving the problem of improving the efficiency of the enterprise in the marketing aspect.

It is important to determine the number of experts. Based on the number of goals reflected in the questionnaire and based on the $95 \%$ probability, a survey of 15 experts is sufficient [27, 28]. After directly interviewing the experts, the information received from the experts is processed and the degree of agreement of the experts is checked, which should be carried out on the basis of the calculation of the concordance coefficient, which is 0.72 . The calculated value indicates a fairly high consistency of experts. It is expedient to check the materiality of the concordance coefficient using Pearson's criterion $\chi^{2}[27,28]$. As a result of calculations $\chi_{\text {resp. }}^{2}>\chi_{\text {tab. }}^{2}(248.07 \geq 35.17246)$, i. e. the obtained value of 248.07 is greater than the table. Thus, the hypothesis regarding the consistency of the opinions of 15 experts regarding the importance of ranking certain goals is accepted.

Based on the survey of experts on the ranking of goals formed a column «goals measures - resources» to increase the efficiency of the enterprise in the marketing aspect.

To achieve the main goal (0.1) it is necessary to achieve the goal of the first level $(1.1,1.2)$. These goals ensure the achievement of the strategic goal and are equally important, i. e. they (1.1 and 1.2) have the same first rank. Current priorities reflect the rank of goals associated with the higher-level goal. To prioritize second-level goals in achieving a higher-level goal, it is necessary to set strategic priorities. Strategic priorities characterize the relative importance of achieving a certain goal in terms of contributing to the achievement of the highest goal. The definition of strategic priorities should be carried out on an ordinal scale [27]. According to this goal, for each of the directions that go according to the arrows from a specific goal to the general, it is necessary to organize the values of the current priorities according to the rule from top to bottom. The resulting number determines the strategic priority in the ordinal scale. The lowest number corresponds to the highest strategic priority.

Criteria for achieving the goals, which were determined taking into account the indicators of evaluating the efficiency of the enterprise by objective and subjective components based on the results of multidimensional factor analysis [16], are presented in Table 3.

Therefore, the criteria presented in Table 3 should be determined by the index method, as the ratio of the actual value of the indicator to its planned or last year's value. Growth will be characterized by the value of the indicator, more than 1. To achieve the goals it is advisable to develop a set of appropriate measures. Therefore, for the purposes of the lowest (second) level, a set of measures was formed that will increase the efficiency of the enterprise in the marketing aspect. The proposed set of measures that is the basis for increasing the efficiency of the enterprise in the marketing aspect is presented in Table 4.

Construction of the column «goals - measures - resources» of the project on growth of efficiency of activity of the enterprise in the marketing aspect is a basis of planning not of separate independent actions, and their mutual set. All this allows to move from planning goals and measures to increase the efficiency of the enterprise in the marketing aspect to the formation of the required resources. 
The next stage of development and implementation of projects to improve the efficiency of the enterprise in the marketing aspect is the formation of alternative ways to achieve the goals that were set.

Restrictions on key project resources were identified in the set of machine-building enterprises under study. This applies to financial, human, production, innovation, marketing and information and communication resources. Therefore, the achievement of each goal of the second level should be ensured by the implementation of one measure, which will achieve it in full, taking into account the existing alternatives.

The next stage is the formation of alternative options for project implementation, based on one of the alternative measures. According to the Table 4 options for the implementation of measures it is advisable to form several options for project implementation to improve the efficiency of the enterprise in the marketing aspect, which are presented in Table 5 .

Thus, based on the information presented in Table 5, the project can be implemented based on the implementation of one of the eight alternatives. Enterprises have certain limitations of financial, personnel, production, innovation, marketing and information and communication resources.

Therefore, when choosing a priority option for project implementation, it is advisable to take into account such limitations as the additional need for financial, personnel, production, innovation, marketing, information and communication support for the implementation of alternative project activities and the priority of alternative project activities.

Table 3

Criteria for achieving goals

\begin{tabular}{|c|c|c|}
\hline Goalt code & Goal formulation & Criteria for achieving the goal \\
\hline 0.1 & $\begin{array}{l}\text { Increasing the efficiency of the enterprise } \\
\text { in the marketing aspect as a whole }\end{array}$ & $\begin{array}{l}\text { The growing value of the generalized integrated indicator for assessing the effectiveness of the en- } \\
\text { terprise in the marketing aspect }\end{array}$ \\
\hline 1.1 & $\begin{array}{l}\text { Growth of efficiency of activity of the } \\
\text { enterprise on an objective component }\end{array}$ & $\begin{array}{l}\text { The growth of the integrated indicator of evaluating the efficiency of the enterprise by the objective } \\
\text { component }\end{array}$ \\
\hline 1.2 & $\begin{array}{l}\text { Increasing the efficiency of the enterprise } \\
\text { by the subjective component }\end{array}$ & $\begin{array}{l}\text { The growth of the integrated indicator of assessing the efficiency of the enterprise by the subjective } \\
\text { component }\end{array}$ \\
\hline 2.1 & $\begin{array}{l}\text { Increasing the quality of professional } \\
\text { training }\end{array}$ & $\begin{array}{l}\text { 1. The growth of vocational training and retraining directly in the workplace, the level of vocational } \\
\text { training. } \\
\text { 2. The growth of labor productivity at the enterprise. } \\
\text { 3. Increasing the number of employees performing research and development. } \\
\text { 4. The growth of professional training and retraining in educational institutions of different types }\end{array}$ \\
\hline 2.2 & Growth of innovation activity & $\begin{array}{l}\text { 1. The growth in sales of innovative products. } \\
\text { 2. Increasing the number of acquisitions of new technologies, results of research and development }\end{array}$ \\
\hline 2.3 & $\begin{array}{l}\text { Improving the financial condition of the } \\
\text { enterprise }\end{array}$ & $\begin{array}{l}\text { 1. The growth of turnover of accounts payable of the enterprise. } \\
\text { 2. The growth of liquidity of the enterprise. } \\
\text { 3. The growth of the turnover of equity of the enterprise. } \\
\text { 4. Increasing the profitability of the enterprise. } \\
\text { 5. The growth of enterprise autonomy. } \\
\text { 6. The growth of financial risk of the enterprise }\end{array}$ \\
\hline 2.4 & $\begin{array}{l}\text { Improving the production condition of } \\
\text { the enterprise }\end{array}$ & $\begin{array}{l}\text { 1. The growth of capital at the enterprise. } \\
\text { 2. Increase in the value of enterprise funds. } \\
\text { 3. The growth of disposal of obsolete funds of the enterprise. } \\
\text { 4. The growth of the suitability of the funds of the enterprise }\end{array}$ \\
\hline 2.5 & $\begin{array}{l}\text { Increasing the efficiency of the com- } \\
\text { pany's brand }\end{array}$ & The growth of the value and strength of the brand by the enterprise \\
\hline 2.6 & $\begin{array}{l}\text { Improving the state of the marketing } \\
\text { infrastructure }\end{array}$ & Increasing the efficiency of the marketing etching information system \\
\hline 2.7 & $\begin{array}{l}\text { Introduction and increase of efficiency of } \\
\text { use of modern marketing technologies }\end{array}$ & $\begin{array}{l}\text { 1. Increasing the effectiveness of marketing research by the enterprise. } \\
\text { 2. Increasing the efficiency of segmentation of the target market of the enterprise. } \\
\text { 3. Increasing the effectiveness of product policy. } \\
\text { 4. Increasing the effectiveness of advertising activities of the enterprise }\end{array}$ \\
\hline 2.8 & $\begin{array}{l}\text { Formation of a system of audit of market- } \\
\text { ing technologies }\end{array}$ & Existence of audit system of marketing technologies at the enterprise \\
\hline 2.9 & $\begin{array}{l}\text { Improvement program (plan) marketing } \\
\text { activities in the enterprise }\end{array}$ & Increasing the effectiveness of strategic marketing management in the enterprise \\
\hline 2.10 & $\begin{array}{l}\text { Constant updating of the purposes and } \\
\text { directions of increase of efficiency of } \\
\text { activity of the enterprise as a whole }\end{array}$ & $\begin{array}{l}\text { 1. Increasing the efficiency of operational management at the enterprise. } \\
\text { 2. Increasing the efficiency of the enterprise to the use of feedback }\end{array}$ \\
\hline 2.11 & $\begin{array}{l}\text { Improving information and communica- } \\
\text { tion support }\end{array}$ & $\begin{array}{l}\text { 1. Increasing the effectiveness of the use of accounting information from the environment. } \\
\text { 2. Increasing the efficiency of the use of information that serves the system of management decisions }\end{array}$ \\
\hline 2.12 & $\begin{array}{l}\text { Improving strategic and tactical market- } \\
\text { ing management, use of regulatory and } \\
\text { scientific and technical information }\end{array}$ & $\begin{array}{l}\text { 1. Increasing the effectiveness of the use of information about the deviation of the values of actual } \\
\text { indicators from the planned in the process of strategic marketing management. } \\
\text { 2. Increasing the effectiveness of tactical management through marketing activities. } \\
\text { 3. Increasing the efficiency of regulatory and scientific and technical information }\end{array}$ \\
\hline
\end{tabular}


A set of measures to increase the efficiency of the enterprise in the marketing aspect

\begin{tabular}{|c|c|}
\hline Measure code & Measure essence \\
\hline 3.1 & $\begin{array}{l}\text { Measures to improve the quality of professional training: } \\
\text { 3.1.1. signing agreements with leading universities, institutes and other organizations for professional development; } \\
\text { 3.1.2. conducting intra-corporate trainings to acquire the latest competencies; } \\
\text { 3.1.3. formation at the enterprise of a system of motivation for professional self-development of each employee }\end{array}$ \\
\hline 3.2 & $\begin{array}{l}\text { Measures to acquire new technologies, research and development results: } \\
\text { 3.2.1. development of a system for the transfer of new technologies; } \\
\text { 3.2.2. implementation of innovation (intermediary activity in the field of technology transfer, which involves the involvement of specialist } \\
\text { providers in the commercialization of innovative developments through consulting, venture financing and innovative business design to } \\
\text { promote innovative products on the market) }\end{array}$ \\
\hline 3.3 & $\begin{array}{l}\text { Measures to intensify the development of new technologies, research and development: } \\
\text { 3.3.1. introduction of a permanent seminar for developers to discuss innovative proposals; } \\
\text { 3.3.2. identification of the list of potential contracting organizations that may participate in the development of innovative proposals; } \\
\text { 3.3.3. formation of a data bank of potential executors of innovative projects both at the enterprise and outside it; } \\
\text { 3.3.4. formation of mechanisms for financing innovative projects at the enterprise }\end{array}$ \\
\hline 3.4 & $\begin{array}{l}\text { Measures to improve the financial condition of the enterprise: } \\
\text { 3.4.1. improvement of the receivables policy of the enterprise on the adaptation of maturities; } \\
\text { 3.4.2. improvement of the credit policy of the enterprise; } \\
\text { 3.4.3. improvement of the depreciation policy of the enterprise }\end{array}$ \\
\hline 3.5 & $\begin{array}{l}\text { Measures to improve the production condition of the enterprise: } \\
\text { 3.5.1. acquisition by the enterprise of new equipment for technological operations in relation to key business processes; } \\
\text { 3.5.2. renovation of existing equipment at the enterprise }\end{array}$ \\
\hline 3.6 & $\begin{array}{l}\text { Measures to improve the efficiency of the company's brand: } \\
\text { 3.6.1. improvement of the individual approach to serving key customers in the enterprise; } \\
\text { 3.6.2. implementation of ChM system at the enterprise; } \\
\text { 3.6.3. improvement of the plan of participation of the enterprise in tenders, exhibitions, fairs; } \\
\text { 3.6.4. development of a plan for internal and external quality audit of the enterprise; } \\
\text { 3.6.5. participation of the enterprise in competitions on quality }\end{array}$ \\
\hline 3.7 & $\begin{array}{l}\text { Measures to improve the state of marketing infrastructure: } \\
\text { 3.7.1. improvement of interaction with marketing intermediaries; } \\
\text { 3.7.2. improvement of interaction with trade intermediaries; } \\
\text { 3.7.3. improvement of interaction with specialists in the organization of product promotion; } \\
\text { 3.7.4. improvement of interaction with advertising agencies }\end{array}$ \\
\hline 3.8 & $\begin{array}{l}\text { Measures to improve the efficiency of modern marketing technologies: } \\
\text { 3.8.1. activation of online advertising of the enterprise (site and online store); } \\
\text { 3.8.2. periodic analysis of repeated visits to the site of the enterprise; } \\
\text { 3.8.3. determining the number of indexed pages of the enterprise in different search engines; } \\
\text { 3.8.4. analysis of the number of links to the company's website; } \\
\text { 3.8.5. analysis of the value of the involved potential or existing buyer of the enterprise; } \\
\text { 3.8.6. analysis of the effectiveness of various sources of attracting customers to the company's website; } \\
\text { 3.8.7. conversion level analysis to characterize the quality of the company's website; } \\
\text { 3.8.8. registration of the company's site in search engines and directories, electronic bulletin board }\end{array}$ \\
\hline 3.9 & $\begin{array}{l}\text { Measures to implement modern marketing technologies: } \\
\text { 3.9.1. application of SMM technology; } \\
\text { 3.9.2. application of SEO optimization of the enterprise site; } \\
\text { 3.9.3. application of SMO optimization of the enterprise site; } \\
\text { 3.9.4. application of banner advertising of the enterprise }\end{array}$ \\
\hline 3.10 & $\begin{array}{l}\text { Measures to improve the audit system of marketing technologies: } \\
\text { 3.10.1. regular internal audit of marketing technologies of the enterprise; } \\
\text { 3.10.2. regular external audit of marketing technologies of the enterprise; } \\
\text { 3.10.3. development of plans to eliminate identified shortcomings; } \\
\text { 3.10.4. monitoring the implementation of the developed plans to eliminate the identified shortcomings }\end{array}$ \\
\hline 3.11 & $\begin{array}{l}\text { Measures to improve the program (plan) of marketing activities at the enterprise: } \\
\text { 3.11.1. annual (and if necessary) updating of the program (plan) of marketing actions at the enterprise taking into account modern tendencies }\end{array}$ \\
\hline 3.12 & $\begin{array}{l}\text { Measures to constantly update the goals of improving the efficiency of the enterprise as a whole: } \\
\text { 3.12.1. analysis of the strategic position of the enterprise; } \\
\text { 3.12.2. identification of opportunities and threats to ensure and improve the efficiency of the enterprise; } \\
\text { 3.12.3. definition of new goals to increase the efficiency of the enterprise }\end{array}$ \\
\hline 3.13 & $\begin{array}{l}\text { Measures to constantly update the areas of efficiency of the enterprise as a whole: } \\
\text { 3.13.1. identification of current trends in the management of financial, human resources, production, innovation, marketing and information } \\
\text { and communication resources; } \\
\text { 3.13.2. formation of the list of offers (according to the revealed tendencies) on increase of efficiency of use of financial, personnel, industrial, } \\
\text { innovative, marketing and information and communication resources }\end{array}$ \\
\hline 3.14 & $\begin{array}{l}\text { Measures to improve information and communication support: } \\
\text { 3.14.1. development of a plan to improve information and communication support; } \\
\text { 3.14.2. regular updating of the plan for improving information and communication support }\end{array}$ \\
\hline 3.15 & $\begin{array}{l}\text { Measures to improve strategic and tactical marketing management, use of regulatory and scientific and technical information: } \\
\text { 3.15.1. implementation of periodic evaluation of the effectiveness of the use of information on the deviation of the values of actual indicators } \\
\text { from the planned in the process of strategic marketing management; } \\
\text { 3.15.2. implementation of periodic evaluation of the effectiveness of tactical management through the implementation of marketing activities; } \\
\text { 3.15.3. constant updating of the database of normative and scientific and technical information; } \\
\text { 3.15.4. inform personnel about the changes taking place in the regulatory, scientific and technical second information }\end{array}$ \\
\hline
\end{tabular}


Table 5

Alternative project implementation options to increase the efficiency of the enterprise in the marketing aspect

\begin{tabular}{|c|c|}
\hline $\begin{array}{l}\text { List of project } \\
\text { options }\end{array}$ & $\begin{array}{l}\text { Codes of measures included in a certain project } \\
\text { implementation option }\end{array}$ \\
\hline 1 & $\begin{array}{c}\text { 3.1, 3.2, 3.4, 3.5, 3.6, 3.7, 3.8, 3.10, } \\
\text { 3.11, 3.12, 3.14, 3.15 }\end{array}$ \\
\hline 2 & $\begin{array}{c}\text { 3.1, 3.3, 3.4, 3.5, 3.6, 3.7, 3.8, 3.10, } \\
\text { 3.11, 3.12, 3.14, 3.15 }\end{array}$ \\
\hline 3 & $\begin{array}{c}\text { 3.1, 3.2, 3.4, 3.5, 3.6, 3.7, 3.9, 3.10, } \\
\text { 3.11, 3.12, 3.14, 3.15 }\end{array}$ \\
\hline 4 & $\begin{array}{c}\text { 3.1, 3.2, 3.4, 3.5, 3.6, 3.7, 3.8, 3.10, } \\
\text { 3.11, 3.13, 3.14, 3.15 }\end{array}$ \\
\hline 5 & $\begin{array}{c}\text { 3.1, 3.3, 3.4, 3.5, 3.6, 3.7, 3.9, 3.10, } \\
\text { 3.11, 3.12, 3.14, 3.15 }\end{array}$ \\
\hline 6 & $\begin{array}{c}\text { 3.1, 3.3, 3.4, 3.5, 3.6, 3.7, 3.8, 3.10, } \\
\text { 3.11, 3.13, 3.14, 3.15 }\end{array}$ \\
\hline 7 & $\begin{array}{c}\text { 3.1, 3.2, 3.4, 3.5, 3.6, 3.7, 3.9, 3.10, } \\
\text { 3.11, 3.13, 3.14, 3.15 }\end{array}$ \\
\hline 8 & $\begin{array}{c}\text { 3.1, 3.3, 3.4, 3.5, 3.6, 3.7, 3.9, 3.10, } \\
\text { 3.11, 3.13, 3.14, 3.15 }\end{array}$ \\
\hline
\end{tabular}

The presented limitations determine a set of characteristics of project implementation options. For each alternative project activity, it is advisable to determine the costs, which determine the required amount of resources and set limits on the above indicators for the implementation of project activities to improve the efficiency of the enterprise in the marketing aspect.

Possible options for project implementation, ensuring the achievement of the main goal, are formed on the basis of a combination of alternative measures, which should be carried out in such a way that the formed set of measures is characterized by the sufficiency and completeness of the project goals. Therefore, the further selection of the priority option for project implementation should be made on the basis of the mandatory inclusion of measures in which there are no alternatives and comparison of the estimated data of alternative measures.

\section{SWOT-analysis of research results}

Strengths. The strengths of research and application of methodological support to determine the main directions of improving the efficiency of the enterprise in the marketing aspect are that this support is based on a modern understanding of the basic theoretical concepts of the study. Namely, «efficiency» and «marketing aspect», characterized by the continuity of each stage, the presence of alternative measures that correspond to the results of determining the effectiveness of the enterprise. In comparison with analogues, the proposed measures provide an opportunity to move to alternative options for project implementation with minimal costs in the conditions of constant transformations.

Weaknesses. The analysis of the process of implementation of methodological support to determine the main directions of improving the efficiency of the enterprise in the marketing aspect showed that in a highly dynamic external and internal environment it is impossible to provide all alternative options for project implementation. Therefore, there is a risk of choosing not the optimal version of the project to improve the efficiency of the enterprise in the marketing aspect, but the most realistic in terms of availability of resources.

Opportunities. It should be noted that in the future the process of implementing methodological support to determine the main directions of improving the efficiency of the enterprise in the marketing aspect can be supplemented with modules for automated formation of information support. In order to generate alternatives for the project to improve the efficiency of the enterprise in the marketing aspect, information support should be based on an adequate and appropriate mathematical apparatus.

Threats. The threats to the introduction of methodological support to determine the main directions of improving the efficiency of the enterprise in the marketing aspect include the fact that the list of measures to increase the efficiency of the enterprise in the marketing aspect will change dynamically under the influence of external factors.

\section{Conclusions}

1. The specified definitions of the concepts «economic efficiency» and «marketing aspect» are offered. The definitions correspond to the provisions of the theories of modern behavioral economics, development and marketing relations. The definition is used as a theoretical basis for the developed methodological support to improve the efficiency of the enterprise.

2. The stages of formation of methodical maintenance on definition of the basic directions of increase of efficiency of activity of the enterprise in marketing aspect are identified. The advantages of the developed methodological support are the continuity of each stage, the availability of alternative measures that correspond to the results of evaluating the effectiveness of the enterprise in marketing, which provides the opportunity to move to alternative options for project implementation in a constant transformation.

\section{References}

1. Khachaturov, T. S. (1979). Effektivnost kapitalnykh vlozhenii. Moscow: Izd-vo «Ekonomika», 384

2. Kuznietsova, O. V. (2014). Shchodo sutnosti ekonomichnoi efektyvnosti. Rozvytok metodiv upravlinnia $i$ hospodariuvannia na transporti, 4 (49), 178-189.

3. Morschenok, T. S. (2016). Research of going near determination of economic essence of concept «efficiency». Economic Bulletin of the Zaporozhye State Engineering Academy, 1 (01), 7-13.

4. Svitlyshyn, I. I. (2015). Typolohiia efektyvnosti funktsionuvannia pidpryiemstva. Visnyk ZhDTU, 1 (71), 110-118.

5. Ambler, T. (2000). Marketing and the Bottom Line: the New Metrics of corporate wealth. London: Prentice-Hall, 325.

6. Anderson, C., Narus, J. A., van Rossum, W. Customer Value Propositions in Business Markets. Harvard business review, 84 (3), 90-99. Available at: https://www.researchgate.net/ publication/7263153 Customer_Value_Propositions in Business_Markets

7. Shaw, R. (2001). Improving marketing effectiveness. London: Profile Books Ltd., 245.

8. Bushuyev, S. D., Wagner, R. F. (2014). IPMA Delta and IPMA Organisational Competence Baseline (OCB). International Journal of Managing Projects in Business, 7 (2), 302-310. doi: http:// doi.org/10.1108/ijmpb-10-2013-0049

9. Bushuyev, S. D., Bushueva, N. S., Babayev, I. A., Yakovenko, V. B., Grisha, E. V., Dzyuba, S. V., Voitenko, A. S. (2010). Creative project management technologies and programs. Kyiv: Sammit kniga, 768.

10. Bushuyev, S. D., Kharitonov, D. A., Rogozina, V. B. (2012). Organizational Project Management pathology. Upravlinnia rozoytkom skladnykh system, 10, 5-8. 
11. Kerzner, H. (1998). In search of excellence in Project Management. VNB, 274.

12. Kerzner, H. (2001). Strategic Planning for Project Management Using a Project Management Maturity Model. John Wiley \& Sons Inc., 226

13. Vlasova, N. O., Pichuhina, T. S., Kruhlova, O. A., Haidar, N. O (2012). Otsinka efektyonosti hospodarskoi diialnosti pidpryiemstv rozdribnoi torhivli. Kharkiv: Monohraf, 196.

14. Hvozdiu, S. Yu. (2010). Methodological approaches of industrial enterprises innovation expenses effiecency evaluation. Bulletin of the National University of Lviv Polytechnic. Problems of economics and management, 683, 184-187.

15. Hovorushko, T. A., Klymash, N. I. (2013). Upravlinnia efektyvnistiu diialnosti pidpryiemsto na osnovi vartisno-oriientovanoho pidkhodu. Kyiv: Lohos, 204.

16. Herasymov, O. K. (2018). Methodical provision of enterprise's economic efficiency assessment in the marketing aspect. Scientific notes of the National University «Ostroh Academy». Economy series, 1 (9 (37)), 32-39. doi: http://doi.org/10.25264/23115149-2018-9(37)-32-39

17. Ralko, O. S. (2011). Pidkhody do efektyvnosti upravliannia orhanizatsiieiu. Naukovi zdobutky molodi - vyrishenniu problem kharchuvannia liudstva u XXI stolitti. Kyiv: NUKhT, 161.

18. Blocker, C. P., Flint, D. J., Myers, M. B., Slater, S. F. (2010). Proactive customer orientation and its role for creating customer value in global markets. Journal of the Academy of Marketing Science, 39 (2), 216-233. doi: http://doi.org/10.1007/ s11747-010-0202-9

19. Boulding, W., Staelin, R., Ehret, M., Johnston, W. J. (2005). A customer relationship management roadmap: what is known, potential pitfalls, and where to go. Journal of Marketing, 69 (4), 155-166. doi: http://doi.org/10.1509/jmkg.2005.69.4.155

20. Bradford, T. W. (2015). Beyond Fungible: Transforming Money into Moral and Social Resources. Journal of Marketing, 79 (2), 79-97. doi: http://doi.org/10.1509/jm.13.0437
21. Brakus, J. J., Schmitt, B. H., Zarantonello, L. (2009). Brand Experience: What Is It? How Is It Measured? Does It Affect Loyalty? Journal of Marketing, 73 (3), 52-68. doi: http://doi.org/ 10.1509/jmkg.73.3.52

22. Brown, S. L., Eisenhardt, K. M. (1997). The Art of Continuous Change: Linking Complexity Theory and Time-Paced Evolution in Relentlessly Shifting Organizations. Administrative Science Quarterly, 42 (1), 1-34. doi: http://doi.org/10.2307/2393807

23. Cambra-Fierro, J., Florin, J., Perez, L., Whitelock, J. (2011). Inter-firm market orientation as antecedent of knowledge transfer innovation and value creation in networks. Management Decision, 49 (3), 444-467. doi: http://doi.org/10.1108/00251741111120798

24. Copley, P. (2004). Marketing communications management: con cepts, theories, cases and practices. Oxford: Jordan Hill, 480. doi: http://doi.org/10.4324/9780080473376

25. Balabanova, L. V., Folomkina, I. S. (2009). Upravlinnia realizat siieiu stratehii pidpryiemstva: marketynhovyi pidkhid. Donetsk: DonNUET, 402.

26. Porter, M. E. (1980). Competitive Strategy: Techniques for Analyzing Industries and Competitors. New York: Free Press, 396.

27. Beshelev, S. D., Gurvich, F. G. (1980). Matematiko-statisticheskie metody ekspertnykh ocenok. Moscow: Statistika, 264.

28. Ventcel, A. D. (1975). Kurs teorii sluchainykh processov. Moscow: Nauka, 320.

Iastremska Olena, Doctor of Economic Science, Professor, Department of Management, Logistics and Economics, Simon Kuznets Kharkiv National University of Economics, Ukraine, ORCID: http:// orcid.org/0000-0002-5653-6301,e-mail: Iastremska_om@hneu.net

Gerasymov Oleksandr, Postgraduate Student, Department of Management, Logistics and Economics, Simon Kuznets Kharkiv National University of Economics, Ukraine, ORCID: http://orcid.org/00000003-2164-2144, e-mail: okgerasymov@gmail.com 